\title{
The Ballyhooed Art of Governing Romance
}

Interest in The Sheik continued to build and a studio press agent was assigned as a buffer between Valentino and the press.

IRVING SHULMAN, VALENTINO, $1967^{1}$

One of the striking characteristics of the era of Coolidge Prosperity was the unparalleled rapidity and unanimity with which millions of men and women turned their attention, their talk, and their emotional interests upon a series of tremendous trifles-a heavyweight boxing-match, a murder trial, a new automobile model, a transatlantic flight.

FREDERICK LEWIS ALLEN, ONLY YESTERDAY, $1931^{2}$

\section{A “Poisonously SALACIOUS” BESTSELLER}

The year 1921 turned out to be magical for Valentino even though the aftermath of the success of The Four Horsemen was anything but rosy. After Camille, he and Mathis left Metro Pictures to join Famous Players-Lasky. It was an ambitious move for both of them, but Valentino was also motivated by his frustrations with Metro's unwillingness to raise his salary and public profile substantially despite the success of The Four Horsemen. Upon learning that Metro underappreciated Valentino's star potential, Jesse Lasky hired him and then paired him with Mathis, whom he had just lured away from the same company, to work on The Sheik. Before their move, Lasky had acquired the filming rights to the eponymous British best-selling novel and for a while remained unsure whether to turn it into a film. The Sheik had first become a smashing success in the United Kingdom, eventually going through 108 printings between its release in 1919 and 1923, but as overwhelming as the novel's British popularity was, it "could not compare with its bedazzling success in the United States."3

The novel had something mysterious about it: the gender of the unknown author, E. M. [Edith Maude] Hull, remained long unclear until it was revealed that she was a first-time female writer. The book was also quite controversial in America not just because it described the repeated rape of a white Englishwoman 
by a man who for much of the novel seems to be an Arab, but also and most significantly because it portrayed the result as a passionate love affair. Although the Literary Review described it as "poisonously salacious in conception" and the New York Times found its story "preposterous," the novel struck a chord among thousands of female readers - which greatly intrigued Lasky. ${ }^{4}$ Still, publishing the book and adapting it for the screen were obviously two different commercial enterprises. At the height of nativist propaganda and a Ku Klux Klan revival in America, the fear of showing and thereby endorsing miscegenation was real and profound. ${ }^{5}$

Hull's The Sheik could circulate freely because it had successful precedents: it belonged to a tradition of romantic novels that had become popular since the beginning of the century and that included Robert Hitchens's Garden of Allah (1904) and Kathlyn Rhodes's The Lure of the Desert (1916). ${ }^{6}$ After her most famous novel, Hull went on to publish other works in the same vein, including The Shadow of the East (1921) and Son of the Sheik (1925), which was adapted into Valentino's last film. Critically speaking, the film and its surrounding literary tradition raises questions about historical female readers' (and spectators') attraction for "desert Arabs, portrayed as barbaric, sensual, dangerous and unpredictable." At issue is the ostensible discrepancy between the early-twentieth-century scripted "fantasies of opulence, barbarism and sensuality," centered on the notion of the Orient as the West's feminized other, and new postwar discourses about gender equality and female identities. ${ }^{8}$ The discrepancy was only superficial. Because of readers' familiarity with the genre, the sheik's dangerous demeanor as kidnapper and sexual predator is never purely shocking. It is mitigated by the narrative tradition within which he operates and which relies on a number of recognizable motifsthe abduction, the sandstorm, the desert ride, and the heroine's futile attempt to escape. This distant but familiar universe ensures that apparently alien characters are "carefully pre-packaged into familiar narrative parcels, which can be enjoyed without undue anxiety." The exciting barbarism of the story's othered, yet highly aestheticized protagonist operates on familiar terrain. At the level of narrative, the stereotypical ideological rivalry between East and West could be both excitingly and safely projected onto Western women's attraction to the sensual and barbaric Oriental man not only because it was a familiar script, but also because its characters engage in masquerades. In both the novel and the film, as we shall see, the two protagonists undergo and display significant transformations that grant ideological legitimacy to their romantic entanglement and enable spectatorial pleasure without erasing the story's racy and dangerous atmosphere.

Famous Players-Lasky purchased the film rights because it apparently appreciated the novel's success among female readers, who constituted cinema's most loyal patrons. Still, visualizing a white woman's dangerous and illicit romance with a racially othered man posed challenges that had to be addressed at the levels of casting, narrative, and promotion. As Lasky recounted in his memoir, he remained uncertain about whom to choose for the leading part of the passionate desert 
savage. He had excluded Wallace Reid because he "was too much the goodnatured, big-brother type" and Thomas Meighan for being "too wholesome and casual." After watching Four Horsemen, he was struck by its unknown male lead who displayed "the lithe grace of a panther" and whose "sheer animal magnetism" made women go to the movie theaters "to swoon." ${ }^{10}$ Because he believed that the newly popular Italian actor could play Ahmed Ben Hassan's performative racial otherness and turn it into a subject of sensual desire, Lasky signed him away from Metro. Although Valentino was quickly on board, June Mathis refused to work on the script because, according to Joan Vale, she "disapproved [of] the sexist theme which focused on physical humiliation, in part desired by the helpless female captive of the desert warrior." ${ }^{11}$ By contrast, American producers feared that Diana Mayo's falling in love with an Arab and being indifferent about the consequences"she did not care what he was, he was the man she loved," says the novel-would have led to major problems with the censors and a sure commercial disaster. ${ }^{12}$

Mathis's refusal to reprise her collaboration with Valentino tells us about the challenge that the adaptation posed (as well as about the opportunities it opened). First, Ibáñez had an artistic reputation that Hull lacked. Second, as the story was written, Ahmed did not appear to be as credibly capable of the kind of conversion that Julio underwent from spoiled young heir to sensitive and irresistible lover. Given how talented Mathis had been in responding to public taste, the film's success vis-à-vis her refusal to collaborate on the project calls attention not just to the differences between novel and film but also to the continuity of the Valentino type first noticed in the promotion of Four Horsemen. Directed by the established George Melford and written by the company's screenwriter Monte M. Katterjohn, The Sheik ended up solidifying the Divo's popular image for years to come.

The film's adaptation was far from a literal adherence to the book. It presented narrative additions and reworkings that affected the construction of the characters and the film's overall ideological register. Since the novel had received wide recognition in America, the film's production, distribution, and publicity largely, although not exclusively relied on audience familiarity with Hull's work. By January 1922 the fan magazines frequently referred to the novel's racy appeal to publicize the film. "Here is romance. Red-hot," promised Photoplay. "If you read the story you will go to see the filmization. If you haven't, you will go anyway." Even though highbrow critics had scoffed at the novel for its sensationalist style and sexually provocative content, the article insisted that it was "read and re-read by two-thirds of the women in this country." ${ }^{13}$ While stressing that the film amounted to sure entertainment, however, the most important fan magazine of its time went on to describe the movie with two apparently contradictory terms: "a very exciting, very old-fashioned photoplay." ${ }^{14}$

The coexistence of these attributes should be surprising. Less than two years after the passage and ratification of the Nineteenth Amendment (June 4, 1919, and August 18, 1920), how could a film that celebrated its dependence on a novel that 
contains rapes and the most controversial form of interracial romance (featuring a white woman, that is) be deemed both "exciting" and "old-fashioned"? Had not years of campaigning for gender equality pushed storytelling to more equitable forms that made sexual violence toward women utterly unacceptable, even as fantasy? Let us consider the circumstances of the film's production and specifically the narrative changes wrought in the novel's story line to assess how the studio released a film that despite its source's controversial plot defied censorship restrictions and was marketed to female fans as most alluring.

\section{(SAFE) DESERT LOVE}

Largely dependent on Hull's narrative arc, the film tells the story of a rich tribal prince, Sheik Ahmed Ben Hassan, who meets a British tourist, the independent Lady Diana Mayo, visiting the Saharan town of Biskra. When she ventures into the desert, Ahmed kidnaps her, takes her to his tent, and tries to seduce her. To his dismay, she rejects him and tries to shame him. Captive and forced to wear traditional Arab garb, Diana is embarrassed to meet one of Ahmed's closest friends, a French novelist named Raoul, who assumes the worst. Fortunately, the novelist and Diana become friends, and Raoul encourages Ahmed to release her. The proud Ahmed keeps her prisoner but, moved by her prayers, no longer tries to assault her. Meanwhile, during an escorted horseback ride outside the camp, Diana scribbles "Ahmed, I love you" on the sand before falling into the hands of Omair the bandit, a character who sports a much darker complexion than Ahmed does and who does not have any of the hero's style and eventual restraint. Ultimately, Ahmed saves her from captivity, but he is injured during the battle. While attending his wounds, Diana learns from Raoul that Ahmed is the orphaned son of an English father and a Spanish mother. As she prays for his recovery, Ahmed awakens and the two lovers finally recognize each other.

In contrast to the novel, Melford's The Sheik developed new ways to turn Ahmed and Diana into acceptable characters and legitimate lovers and subjects of desire and identification for film audiences. Notwithstanding its debts to the novel, the film includes two complementary sequences that reveal Ahmed and Diana as masquerading characters. The scenes show that, despite the exoticism of settings, costumes, and story, Ahmed and Diana are much more conventional, or "old-fashioned," than they first appear to be. The two sequences strengthen the protagonists' characterizations as individuals devoted to romantic love, and both additions resonate with scenes that were in the novel-particularly one from the beginning that depicts Ahmed's repeated singing and Diana's reactions to it.

The film opens with a set piece, the "bride market" scene in which Ahmed takes part in the "ancient custom by which wives are secured for the wealthy sons of Allah," as one intertitle reads. After noticing how the traditional custom would end up separating two true lovers, he exercises his authority in favor of authentic 
romance. The importance of the scene is proleptic: "It makes clear that his erotic imagination," observes Stephen Caton, "can warm to the concept of romantic love, by means of which he is subsequently subdued and won over by Diana." ${ }^{15}$ Ahmed appears to be an Arab sheik, a creature who is allegedly foreign to Western notions of romance. In truth, he is only masquerading as an Arab sheik and the coupling of the scene with audiences' knowledge of his true diegetic (and extradiegetic) identity as a European man introduces a double layer in his reception. We may see him as an Arab male chauvinist, but the story constitutes a safe fantasy with a conventional outcome - a foreseeable and familiar romance ending in marriage.

This initial scene frames the film's narrative and the spectatorial experience on two interrelated levels. It provides the original sign of Ahmed's inner nature and as such anticipates his transformation into a character devoted to romance-a change that will also extend to Diana. The scene also trains the spectator in appreciating the visual and dramaturgic solution of the self-exoticizing masquerade that enables the two protagonists to engage in the practices of racial cross-dressing that are consequential for their romance. While this may seem obvious for Ahmed, it is truer for Diana. Initially, she "is a prototypical desert romance heroine," who "flaunts her independence," has a penchant for "boyish clothing," and appears "uninterested in traditionally feminine pursuits."16 Despite these characteristics, Diana is not exactly equivalent to the American flapper, who was known for being sexually active and appreciative of constant courtship. Diana has never kissed a man, does not understand the attraction of physical contact, and lacks the contentment with her femininity that Arab women seem to display. Being in the desert and knowing Ahmed will change that.

Their first direct encounter is an exchange of gazes that reveals his impenitent desire and her fear. But the next morning, Ahmed's passionate singing from afar of "The Kashmiri Song" ("Pale hands I loved beside the Shalimar. Where are you now? Who lies beneath your spell?") stirs a profoundly sensual feeling in Diana. ${ }^{17}$ She remains utterly enchanted, ignoring that her captor is the performer. While describing her reaction, the novel defines his charming and passionate baritone as "strangely un-English." By contrast, the romanticism of the film's first scene of the bride market compels the spectator to register her listening enthrallment as an aural sign of the two protagonists' inevitable romance. His singing reveals a romantic passion that is utterly absent in her brother and her peers. Diana recognizes the song, names it, and is pleasurably reminded of India, and thus of a context of both racial difference and interracial attraction..$^{18}$

Along the same lines, the filmmakers added another scene not included in the novel that fits with Diana's transformation from self-righteous interloper to caring wonderer and finally lover. While in Biskra, Diana intentionally practices racial cross-dressing. She persuades an Arab woman to lend her clothes so that she can masquerade as an Arab wife-to-be and access the casino's inner chambers where local chieftains gamble for brides. Once there, she becomes both a 
horrified witness to the barbaric ritual she so despises and a participant in it, while briefly hidden in plain sight as a native woman willing to accept a sexual sacrifice. Yet, in "her disapproval of these Eastern injustices, she sets up criteria against which the sheik is measured." ${ }^{19}$ The film's initial scene, in which Ahmed authoritatively rejects the Arab custom in favor of true love, sets up Valentino as capable of shifting from primitive sheik to fully acceptable romantic partner. It is a transformation that has both moral and racial implications: its unfolding exposes the civilized nobility of Ahmed's whiteness. Similarly, once Diana's masquerade is revealed by her different skin color, she can escape the primitive ritual for exactly the same reason, thanks to her race. But the cross-dressing has touched her. Only after wearing the costumes of a culture that she judges as primitive can she attain the power to immerse herself in what she considers one of its most barbaric rituals and eventually exit it. Karen Chow notes that female spectators "who identified with her participated, by proxy, in the crossing of gender and racial boundaries as Diana's changes of clothing give her the power of transgression through masquerade." ${ }^{20}$ It is an exciting but safe journey. The scene reveals that racial masquerading is not just an opportunity for Diana to trespass in an alien culture but also a chance to "try on" an alien dimension of her own life, that of wife-to-be, ready for the kind of full sexual experience in which she had long expressed no interest.

At the center of these racial masquerades, at once exoticizing and domesticating, is the Arab desert. More than a geographic location, the desert was the projection of rich and long-standing Orientalist visual and literary imageries that had turned it into a site of daring sexual license. ${ }^{21}$ Since the beginning of the century, the so-called desert romance contributed to such imagery in a remarkable way: it "proved a particularly rich genre for popular engagement with fantasies of sexual identity." ${ }^{22}$ Specifically, in the imaginary desert, women could find freedom from the ideological boundaries of prescribed gender roles through their identification with the sensual Orientalist fantasy that featured unprecedented degrees of explicitness and even violence. In both novel and film, the character of the desert sheik Ahmed animates these fantasies of sexual license. He daringly sexualizes Diana's persona by recognizing her masquerade as a modern woman who refuses to acknowledge her true womanhood. Immediately after kidnapping her, he recognizes her desert clothes as deceptively manly ("You make a very charming boy, but it was not a boy I saw two nights ago in Biskra") and forces her to display her full figure by commanding her to wear Arab garments which accentuate bodily contours. ${ }^{23}$ Even more strikingly, he interpellates her sexual knowledge in an all too explicit fashion, but he does so by advancing a very modern notion of womanhood. After a scared and horrified Diana asks him, "Why have you brought me here?" Ahmed replies with the famous line "Are you not woman enough to know?" which addresses her as a woman who is familiar with erotic desire and is not just drawn to romantic entanglements.

These exchanges invite a consideration of the film's mysogyny in a broader diegetic and cultural context. On the one hand, it is striking to note that through 
Ahmed's brutal conquest (and in the novel through explicit and repeated rape), Diana attains a degree of sexual maturity and emotional self-knowledge that she had lacked. On the other hand, as Karen Chow maintains, the shift from initial asexuality to full-bodied erotic knowledge gave both her and women in general "a new sexual freedom as desiring subjects." ${ }^{24}$ In other words, both novel and film must train their consumers to look past the sexual violence toward its transformative effects-diegetic and extradiegetic. The challenge is to develop strategies to dedramatize Ahmed's barbaric violence and highlight Diana's power to affect change in his heart. Both his racial and gender masquerades must be obvious in order to ensure the feasibility and authenticity of his later conversion. By displaying both the appearance of an outward racial difference and its own performative quality, the film, much more than the novel, enhances the acceptability of its star actor's diegetic conversion. Caton has noted that "the sheik, not Diana, is at the heart of the cinematic melodrama," and he appears "much more 'feminine' to begin with than his novelistic counterpart." ${ }^{25}$ His long flowing robes, his fastidious sophistication, and his visible makeup undermine the threat of his darker, racialized masculinity by revealing a sort of refined and androgynous character. Valentino-as-Ahmed is always impeccably dressed, appears clean and urbane, even in his display of primitive desire. Overdetermined as a seeker of scopic pleasure, he also lends himself to erotic contemplation on the part of other characters and, of course, the film's spectators. He is also quite learned and fluent in many languages, has studied in Paris, and is acquainted with established writers, including Raoul de Saint Hubert. What sets him apart from all the Arabs around him is that he is at home both in the desert and among cosmopolitan (Western) individuals. The true villains, as the film makes clear in the second part, are the "real" and much darker Arabs, who cannot cross-dress culturally, let alone racially, in the way he can. To return to Bederman's framework, an apparent display of racial and national otherness was needed to rework conventional manhood into a romantic and passionate masculinity capable of taming Diana's novel and independent female type. At the same time, the film also uses Ahmed's feminizing features as indexes of personal sensibility and probity to tame his alleged racial otherness and to signal his covert racial nobility. ${ }^{26}$

The person who catalyzes Ahmed's rediscovery of his personal moral sensibility is Diana. Her personal faith enhances and validates his transformation from abusive kidnapper to conflicted, melancholic, and respectful companion. If we ask what keeps Ahmed from further violating Diana after the kidnapping-at least to the degree that the film reveals-we find the repeated scene of Diana praying, which awakens his compassion and remorse. ${ }^{27}$ "It is she [. . .] who tames and redeems him," Caton has noted, "largely through her Christian faith." ${ }^{28}$ Even before the unveiling of the racial/national masquerade, it is his respect for her Christian devotion and thus to Western civilization that informs his change of behavior and ultimately abates the horror of miscegenation. That horror is instead conveniently 
displaced onto the darker and morally unrepentant Sheik Omair, representative of Christianity's "arch adversary, Islam." ${ }^{29}$

As the spectator may surmise at the end of the film, Ahmed's inner whiteness and Christian nobility justify Diana's attraction to him. It is not a total discovery, of course, on either fictional or biographical grounds. Having read the novel, film spectators recognized the film adaptation's narrative twists. Further, while Hull simply invented the fictional Ahmed, Lasky's casting of Valentino made filmgoers unfailingly aware of the character's underlying whiteness. Thus, the realization that Ahmed is not really an Arab but a European, with English and Spanish blue blood in his veins, provides a much more surprising and ultimately reassuring closure in the novel than in the film. Readers of the novel were also exposed to a much more daring and unconventional version of Diana's desire than viewers of the film. Without the aforementioned added scenes, the novel's racial distance between Ahmed and Diana remained far more deep-rooted than in the film. What remains true for both novel and film is that "for the desert romance heroine, marriage with the sheik provides the best of both worlds: a domestic life and [.. . ] exotic presence in her life." ${ }^{\circ}$ The thrill of a dangerous relationship had found a most reassuring last-minute resolution.

Famous Players-Lasky knew very well that the success of The Sheik depended on shrewd and glamorous publicity. In October 1921, a month before the film's release, the director of Paramount publicity, Jerome Beatty, asked his London representative to interview Mrs. Hull. The assembled information was incorporated in a publicity campaign that Paramount described as "one of the biggest ever put behind a motion picture." ${ }^{11}$ The studio and Chalmers Publishing Company played what we may call the audience-pleasing game by linking the book and film. Book editions carried a special jacket designed to tie "directly with the picture through the printed line, 'A Paramount Picture with Agnes Ayres and Rudolph Valentino-a George Melford Production.'” That jacket sported a color reproduction of a painting by popular illustrator Marshall Frantz that had been used in the twenty-four-sheet posters and other advertising illustrations (figure 16). ${ }^{32}$ The publisher meanwhile was "20,000 volumes behind in orders" and had "planned to use the twenty-fifth edition simultaneously with the release of the Paramount picture [...] to advertise the double event in a manner befitting the occasion." ${ }^{33}$ The studio's promotional tie-in squarely stressed the theme of interracial love on and off screen and offered a titillating homage to an Oriental style of courtship that was unapologetically passionate and even despotic. What is more, the promotion justified itself as merely an attempt "to satisfy the public's expectations," Lasky boasted to Moving Picture World. ${ }^{34}$ "A photoplay of tempestuous love between a madcap English Beauty and a bronzed Arab chief" read a double-spread advertisement in $M P W$. It included a line from the novel that was used in the film: "When an Arab sees a woman he wants, he takes her" (figure 17).35

The star-centered promotion worked. The film was a box-office success. On November 10, a Wid's news item reported that the picture, with almost 54,000 

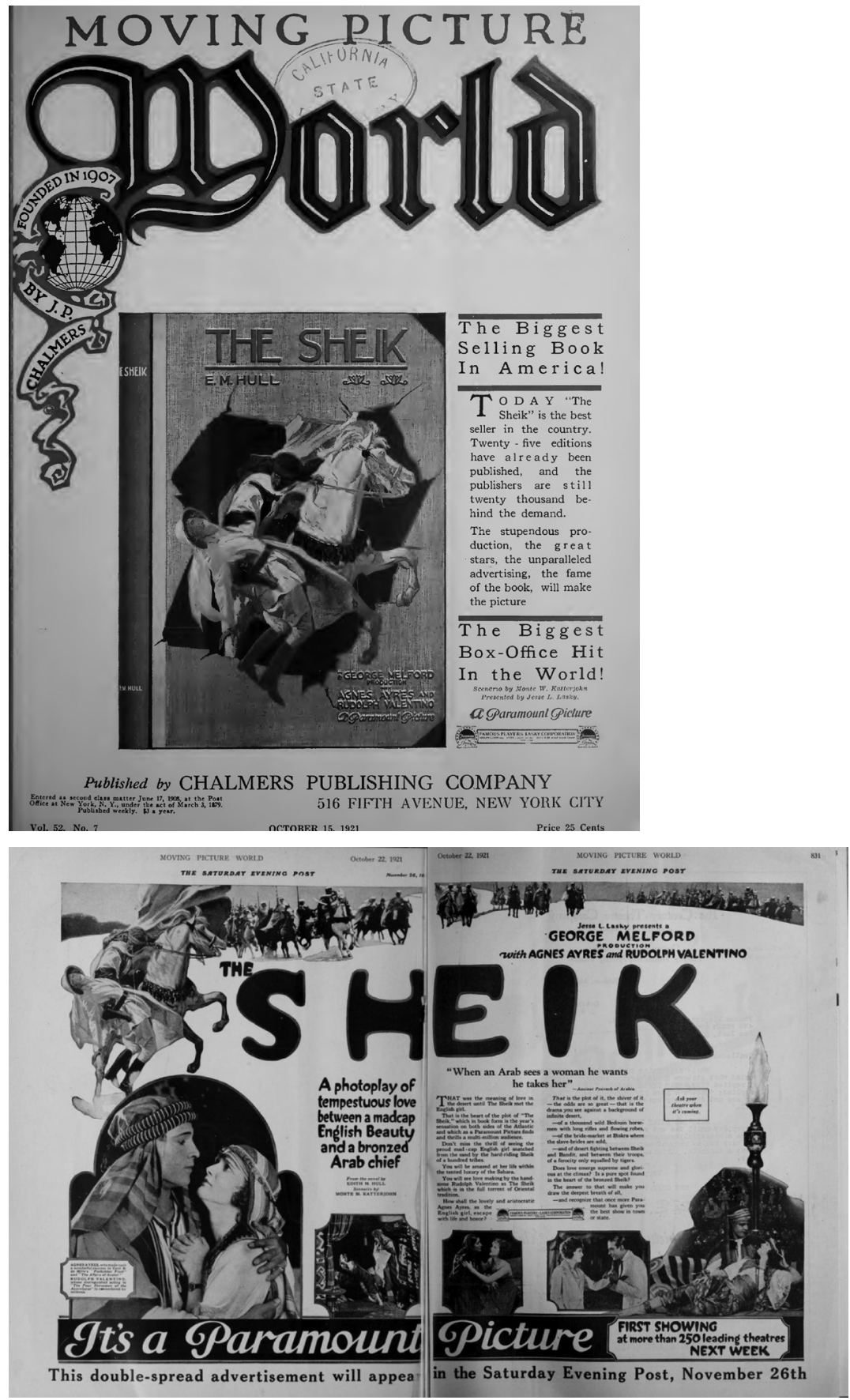

FIGURES 16 and 17. Advertisements for The Sheik (1921). Moving Picture World, October 15, 1921, 713; and Moving Picture World, October 22, 1921, 830-31. 
paying spectators, had "smashed all attendance records at the Rivoli and Rialto theatres" in New York during the first three days and was on track to establish "a new record in Broadway entertainment history". ${ }^{36}$ After its release, a number of articles sought to brand the film as a Valentino-style romance. With pages filled with images and only a few lines of text, Motion Picture Classic, for instance, promoted the film as a unique opportunity to learn about the type of romance that Diana experienced-“desert love." 37 But another dimension emerged as linked to Valentino's diegetic and extradiegetic public authority, one pertaining to a novel model of leadership. It was still intertwined with notions of romantic entanglement, but it was also easily readable in political terms. After all, The Sheik had started as a story about the whims and desire of a charming Oriental despot.

\title{
WHITE LEADERSHIP AND THE ART OF PLEBISCITE
}

\author{
The Sheik, Ahmed Ben Hassan, upon whose shoulders has fallen the heritage \\ of leadership. \\ Growing to manhood as an Arab, he was sent to Paris to be educated and \\ [...] returned to the desert to assume leadership of the tribe. \\ THE SHEIK (1921), INTERTITLES FROM THE OPENING AND CLOSING \\ SCENES
}

With Bederman, we learned that in the early twentieth century, the older formulation of manhood as moral character was eclipsed by an understanding of masculinity that relied on the bodily traits of prowess and sensual appeal and not solely on the moral values of probity and self-control. The legitimation of such elementary traits, often romantically narrativized through racial masquerade, went hand in hand with praise for leadership. Consider the Argentinian tango: in general, it provides a sanctioned acting out of a primitive form of male dominance that relies on the collaboration of a subjugated partner. The recognition of Valentino's tango expertise signified both the actor's embodiment of a primeval appeal and his partner's devoted consent. Similarly, consider Edgar Rice Burroughs's Tarzan of the Apes, featuring an aristocratic British child, John Clayton, raised by apes who call him "Tarzan" (White Skin); he is at once at home in the jungle and instinctively noble. Or consider the British diplomat and officer T. E. Lawrence who, dressed as a Bedouin, managed to lead an Arab revolt against the Ottoman Empire in the context of Britain's African front in World War I. ${ }^{38}$ Tarzan, Lawrence of Arabia, and The Sheik (both novel and film) relied on the expedient of racial masquerade to exhibit a new form of white masculinity that exercised effective leadership over nonwhite crowds-or apes.

Since what keeps these figures from going fully primitive are the sensibility and restraint that allegedly are proper to the white Anglo-Saxon man, the problem with this racial profile is that the Italian Valentino is not one. How was it possible that, given his racial status, he was placed in a position usually occupied by eugenics' 
top-ranked individuals? Ahmed's progressive acceptability and the revelation of what lies beneath his racial masquerade, in fact, calls attention not just to the racial status of the character but also to that of the actor playing it. Thus, for Valentino, there were questions regarding his adequacy not just as a romantic partner for a white woman but also as a leading subject of American audiences' appreciation and desire on and off screen. Taming the feminization of his character and persona and recuperating his otherness as acceptable leadership relied on three dynamics: his differentiation from other characters within The Sheik, his juxtaposition to Italian immigrants' cultural and racial makeup, and a talent to secure plebiscitarian consensus.

Diegetically, The Sheik juxtaposes Valentino against characters who appear to be chromatically and thus racially different. Valentino's leadership is exercised over figures who are clearly darker, including, close to him, a Nubian house servant played by an uncredited African American actor. By the same token, the rival sheik is an unmistakably darker Arab (a white man in blackface), whose even darker bodyguard safeguards Valentino's racial otherness from any possible diegetic or ideological confusion with nonwhite characters or darker-appearing crowds.

In the racial framework of the period, Italians as Europeans enjoyed legal, political, socioeconomic, and social advantages of whiteness that were unavailable to Latino, Native, Asian, and African Americans. ${ }^{39}$ Still, Italians were not exempt from charges of radical racial difference and anthropological inadequacy. Racialization was thus the terrain on which narratives of adaptation could be denied or allowed. As a native Italian, Valentino was heavily racialized, but his status had to be differentiated from that of his fellow Southern Italian immigrants. It is within this framework that one can understand the strategy at work in the phrenological profile that appeared in a March 1922 issue of Photoplay. In it, Valentino emerged as "the Physical-Romantic type," who "is fond of romantic and dangerous action." It was a characterization that, both in its nomenclature and explanations, sought to turn the inevitable identification of racial difference into a set of appealing features, the most remarkable of which were unapologetic individualism, sexual desire, and leadership:

His strong, heavy chin and jaw indicate aggressiveness combined with an accentuated ego and a marked self-esteem. His features (especially his eyes and mouth) show that he is strongly attracted by the opposite sex [... . The vertical structure of his back-head does not permit of his being influenced or taking on impressions easily. ${ }^{40}$

As an exceptional migrant of semiaristocratic background, Valentino had to be positioned above the fray, as a leading man capable of eliciting reactions that were stronger than mere acceptability. Beyond his screen presence, publicity coverage translated the distinct, original, and un-American novelty of the Italian divo into captivating, anticonformist individuality. At the center of editorial-like articles, interviews, and promotional news was the columnist and secret publicity agent 
Herbert Howe. Possibly more than anybody in the 1920s, Howe displayed a peculiar fondness for writing about film stardom through the language of institutional politics and by comparing Hollywood stars to celebrated political leaders-from Napoleon to Mussolini. During the brief but productive collaboration between Howe and Valentino, which lasted until early 1923, the Divo signed off on rare but studied pronouncements that merged film stardom with politics. Howe likely ghostwrote these and inserted them in his profiles of the Italian actor. In these, Howe walked a fine line between highlighting Valentino's charming and sophisticated foreignness and underscoring the agreeable character of his forceful ideas. Recent criticism, while productively engaged in reading Valentino's ambivalent gender image and mode of address, has largely overlooked this political dimension, which first surfaced in coincidence with The Sheik's release.

In the December 1921 issue of Motion Picture Classic, Howe published an extensive profile-interview of Valentino entitled "Hitting the Hookah with Rudie." The actor contributed to it with a wealth of biographical details. ${ }^{41}$ As a way of introducing his subject, Howe first sought to overcome the obstacle of national prejudice. While showing intimate knowledge of his subject, Howe depicts Valentino's arrival in the United States as the result of glamorous, cosmopolitan meandering. "His life has been tempestuous melodrama," he writes admiringly, "commencing in a noble family of Taranto, Italy, passing thru escapades in Paris, curious and sensational adventures in New York, on up to the present moment of screen idolatry." ${ }^{42}$ Then Howe makes sure that the actor's temperament, and not just his life circumstances, can in no way be associated with the culture of the familiar "alien-intruders"-Italian immigrants. For Howe, Valentino displays only good Italian qualities, such as "emotional warmth," but "none of the volubility that we have come to expect as an Italian characteristic thru commerce with push-cart financiers." Instead, the actor has the "dreamy melancholy of the stoic" and although "he has more the facial appearance of the Bedouin than the Roman," he displays "the sturdy muscled physique of the Roman gladiator." The celebration of Valentino's membership in European aristocracy on his mother's side was utterly fictitious: she was not aristocratic, only French. But it resonated well with the appreciation of his cosmopolitan sophistication that further separated him from Italian immigrants. ${ }^{43}$

In the same profile-interview, Valentino effortlessly combines discussions of marriage and women's rights with his take on democracy and the meaning of leadership in both political and romantic affairs. First, he blames divorce on what Howe calls the "democratic delusion," then he moves "from the dangerous subject of woman's rights to the theories of government." For Valentino, democracy was as bad a word as anarchy, whether in a person's private or public affairs:

In America democracy has been carried even to the home and you see the consequences. There must be a leader for a nation, for a state, for a home. There is no such thing as equality. The woman is not the equal of the man, intellectually or any other way. ${ }^{44}$ 
Valentino's celebration of male authority did not actually match some key events in his personal life that had become public knowledge. Shortly after the success of The Four Horsemen, in fact, his life had began publicly unraveling. In May 1921, his first wife, Jean Acker, with whom he did not spend a single night, had accused him of desertion. Shortly after, his domestic affairs were "aired in a Los Angeles courtroom," as Photoplay noted. ${ }^{45}$ The public coverage of his marital fiasco in 1921 and subsequent divorce from Acker (January 1922) shaped a public perception of Valentino as weak, dependent, and exploitable by strong women.

It was this context that gave Valentino and Howe's public celebration of male authority more than a whiff of overcompensation. It was meant to recast Valentino's image and position him as an idealized romantic partner with the personal standing to display effective self-governance and forceful authority over women. Vocally against women's right to vote, he critiques the self-repressive and excessively compliant male American temperament. He takes pride in his Italian origin, but he does so in a recognizably American manner. Valentino stresses the key tenet of individualism a short ten months before Mussolini's March on Rome (October 1922) made the Duce an admirable model of effective autocracy. He thus presents the old-fashioned (yet never passé) Italian individualistic ethos as traditionally American, as if twentieth-century progress had brought decadence and corruption to the New World. He repeatedly praises personal freedom and authority as values lost in the American political system but alive and well in the Italian monarchy:

Not because I am Italian do I say it, but I do believe the Italian form of governmentand the English-gives more individual freedom than the republic [...]. Here in America they attempt to dictate what you shall see on the screen, what you shall put in your mouth-even what you shall do on the day the Lord gave you. Bolshevism is just another democratic theory and it will fail. ${ }^{46}$

In Howe's striking prose, Valentino conflates types of political governance with forms of individual freedom. He judges the modern phenomena of mass consensus and persuasion as conformist perversions and, as such, most un-American. Within a rhetorical framework constantly centered on gender difference, he recognizes the most glaring effects of what he describes as a Bolshevik democratization at the intimate level of romantic relationships. American women's sense of independence and initiative, in his view, result from men's failure to exercise close supervision and authority over their partners. When he returns to the issue a few months later in a comparable article-interview, he advances a familiar autocratic solution: "There must be a leader, one sex or the other, and women in America have found that the men are not leading them. Commercially, the initiative of the American man is supreme on earth. Socially, domestically, he is subordinate." 47 Beyond gender differences, Valentino also comments on the issue of individuals' sovereignty or control over their lives. Despite the "finest educational system in the world," Americans puzzle him. "You do not think, except in masses," he charges, 
"You hide your individuality. You accept. That is the sum of it. The newspapers propound and you accept." In Europe, he claims, even without a comparable level of mass literacy, "the so-called reforms established here" would never be accepted. There, "education or no education, each person is an individual." 48

As Valentino's criticism of the limits of American manhood bled beyond the domain of romantic relationships into the political domain of forms of government and responsible citizenship, Howe too deployed political references-electoral ones, specifically-to read the phenomenon of stars' popular consensus. His columns presented a wealth of political metaphors that equated spectators to "electoral constituents." His views about who is a film star, who makes stars, and who approves them relied on an apparently obvious analogy between stardom and the electoral process and depended on two poles: a star's personality and the public's ability to celebrate it. ${ }^{49}$ Conveniently, he ignored the idea that a studio's publicity efforts played any determining role in the process. The notion of audiences' spontaneous consensus was obviously a trope the industry cultivated in its continuous aspiration to bypass censorship restrictions. It was also an argument that gossip writers like Adela Rogers St. Johns presented somewhat ironically to their readers with such slogans as "Nobody can make stars of nothing." ${ }^{\circ}$ Free choice helped frame Hollywood as an industry that catered to the desires of the audiences and thus ultimately served American democracy, against the arbitrary actions of state and local censorship boards. This was also the very serviceable rationale deployed by fan magazines, directors, and individual critics. ${ }^{51}$

Officially, Howe's ideal model was that of a direct democracy that celebrated fans' unprompted agency in the choice of their favorite stars. In truth, he knew that such a democratic model was a fiction. After Valentino's fame emerged, Howe contended, "the critics and the public pronounced him a 'find,' but of course the critics and the public know nothing about pictures. They only patronize 'em; they don't make 'em." ${ }^{2}$ In other words, the public expresses a free and direct opinion about a candidate only by way of accepting or refusing a proposal that it did not frame or articulate in the first place. Howe also believed in the inevitability of a star when endowed with a novel, appealing personality. Valentino easily embodied an exoticism of manners that young Americans could appreciate as a relief from the "cleanliness [that] makes them believe in their godliness." ${ }_{33}$ Howe's favorite way to reconcile these two positions - the public's mere power of ratification and the star's inevitability-was to make a comparison with the plebiscite. The fan community, just like an entire electorate, is simply invited to ratify or reject an appointment that, in case of a successful outcome, allows stars to behave according to unconventional rules and exercise a unique authority over their base. In politics, plebiscites or decrees by the people turn elected leaders into imperial figures who are virtually unaccountable except during new elections or impeachment. It is not difficult to understand why such plebiscitary logic soon encouraged Howe to associate film stars with authoritarian political leaders-particularly Mussolini. Even more 
importantly, it is also possible to recognize arguments in Howe's political views that do not necessarily involve dictatorships or antidemocratic leaders. As a reference point, I would suggest returning to Woodrow Wilson's pre-twentieth-century writings on political sovereignty.

In his 1893 volume An Old Master, and Other Political Essays, Wilson called for an expansion of executive power in light of his diagnosis about the "nature and lodgment of sovereignty." Distinguishing between government and the process of governing, Wilson questioned the rhetorical and routine identification of sovereignty with the will of the people. He first defined sovereignty "as the highest political power in the state, lodged in active organs, for the purpose of governing." Then he distinguished between sovereignty and control: if "sovereign power is a positive thing; control [is] a negative thing." He concluded that if "power belongs to government [, ... . control belongs to the community," and if power "is lodged in organs of initiative", control "is lodged with the voters." ${ }_{44}$ To read Howe through the lens of Wilson's political writings, one may restate the former's argument by positing that film audiences, like regular voters, may think they are exercising their consecrated sovereignty when casting their ballots for their favorite stars. In reality, their preferences are, to quote Wilson, "exercised by way of approval or disapproval, acquiescence or resistance; they are not agencies of initial choice," ${ }_{55}$ or, to quote Howe again, spectators “only patronize [stars]; they don't make 'em." Wilson's argument in that volume may further illuminate Howe's less-than-forthcoming position regarding the "true organs of initiative." Decades before establishing the CPI, Wilson had expressed his deep concern about the arbitrary and aggressive power of the press, which he recognized as uniquely capable of "assuming the leadership in opinion." ${ }^{6}$ Unlike Wilson, Howe was in convenient denial about the power that he, film periodicals, and studios' promotional campaigns exerted on whom to celebrate as a star-or, to put it differently, on whom to include on voters' ballots.

Howe wrote repeatedly on the unmediated relationship between a star's personality and voters' preferences. In a contribution to Photoplay entitled "They Can't Fool the Public," he praised American spectators for recognizing the novelty of Valentino's exotic personality and casting their votes accordingly, for "the regular motion picture public is infallible in its election of stellar favorites." 57 In response to the widespread view that the studios' promotional activities played an important role, Howe described filmgoing as the only model of actual popular sovereignty:

Fortunes have been expended in publicity and in lavish production to force a player into favor-but to no avail. You can stuff a ballot box, but you can't stuff a box office. Here is one democratic institution where the public will prevails. ${ }^{58}$

Finally, the collaboration between Howe and Valentino was also evident in the actor's serialized autobiography, which Howe likely ghostwrote. ${ }^{59}$ Entitled "My Life Story," it ran in three Photoplay issues from February to April 1923. Earlier that year, a one-page announcement in Photoplay repeated the familiar notion of 
a direct, semiconfessional autobiographical tale: "This is his story. Not his press agent's; he hasn't a press agent. It is the first authentic record of his life, related by himself." 60 This was also the register allegedly adopted by Valentino himself in an "open letter to the American Public" that appeared in the same January 1923 issue right as the actor was engaged in a legal battle with Famous Players over his salary. In it, Valentino sought to explain his refusal to make "cut-and-dried program features" in favor of more artistic projects. His motivation for writing the letter in appeal to the American public was the familiar tenet that the audience holds all the cards. "You discovered me and created me," he wrote with rhetorical gratitude. "You made theater managers know me and you caused film magazines and newspapers to be conscious of me." ${ }^{61}$

The appeal to unmediated democratic consensus allowed Howe to draw comparisons between film stars and Prime Minister Benito Mussolini. Like that of a film star, Mussolini's personality, Americans understood, engendered a direct rapport with the Italian public. After the March on Rome, references to Valentino's autocratic public persona began to assume new political attributes. Writing from Europe in early 1923, Howe commented on the two celebrities in terms of the undivided enthusiasm each received. "The most applauded men in the current world are Valentino and Mussolini," Howe proclaimed. He went on to equate the establishment of a new form of government with the release of a film: "In Rome we witnessed the Fascisti revolution and cheered for Mussolini and Vittorio Emanuele. In London we witnessed Blood and Sand and cheered for Valentino." ${ }^{2}$ In the same issue, he also wrote an article entitled "What Europe Thinks of American Stars." In it Howe wondered "what reception Italy [would] give to [Valentino]" since his films had not yet been released there, and he sought to compare Italian and American audiences on the basis of their shared attraction to exotic figures. ${ }^{63}$ However, the cartoon that Photoplay's editors paired with Howe's piece made a much more interesting comparison (figure 18). Drawn by the renowned illustrator Herb Roth, the cartoon and its accompanying caption imagined the Roman social and architectural landscape for a hero's welcome. Tied across the columns of ancient ruins is a giant poster carrying Valentino's name (in its latest form) above an image of the star attacking a bull—clearly an homage to Blood and Sand (1922) amidst colorful individuals of all classes happily dancing, greeting their hero, and congratulating each other. Even a carabiniere, or police officer, visible in the lower right corner, cannot help but join what appears to be a harmony of passions, a communion of interests that the celebrity has catalyzed. Given the historical moment, the caption alerts the reader: "This is not the Fascisti revolution celebrating the victory of Mussolini, but merely the Roman welcome to the all-conquering Valentino." ${ }^{4}$ It is a legitimate, albeit ironic, notification. The sight of a crowd of excited Italian supporters gathered under the same banner amidst architectural ruins may point more to a spirited plebiscite for the Duce than to the gathering of a throng of film fans. 


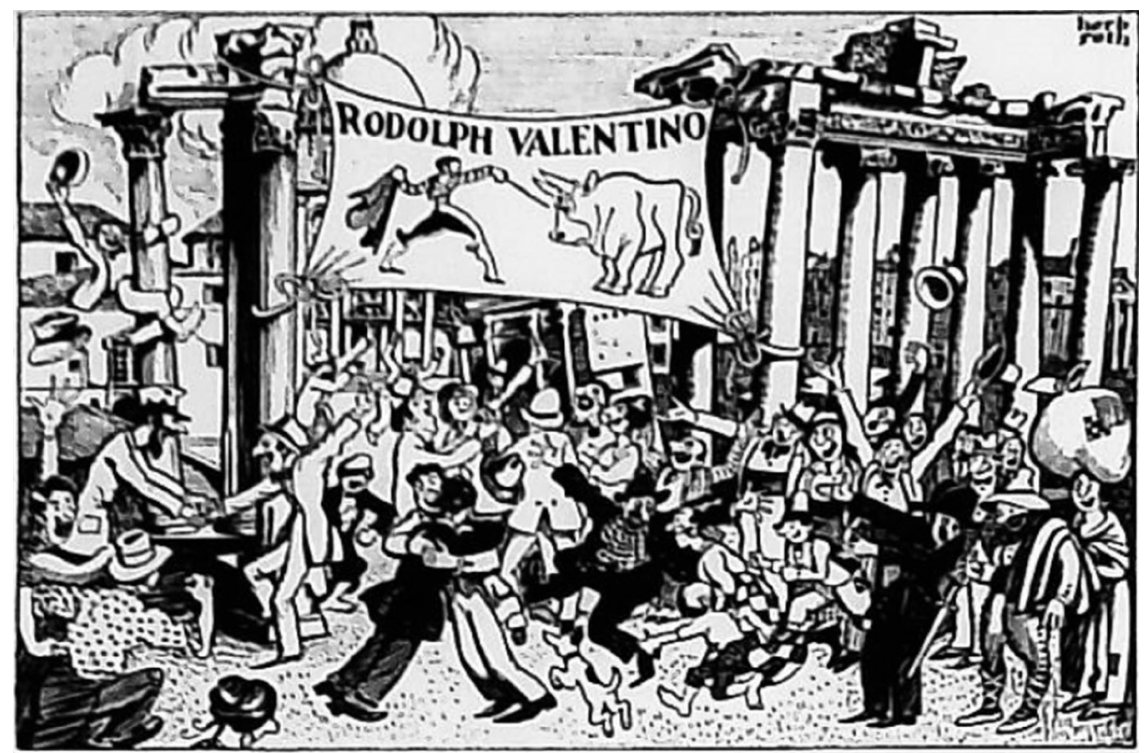

FIGURE 18. Herb Roth's illustration for Herbert Howe's "What Europe Thinks of American Stars," Photoplay, February 1923, 97.

Howe's comparisons to Mussolini centered on overt admiration of the Italian prime minister's forceful manners and his mastery of public performances and promotional strategies. Howe felt that comparisons to the Italian dictator constituted an appropriate reference not just for Valentino but also for another major Hollywood star of the time, Mary Pickford. In a 1924 Photoplay interview with America's sweetheart about her favorite stars and her own career, Howe first reported how Pickford sympathized with Valentino's decision to quit Famous Players in opposition to the commercial demands put on him. When talking about her own future and expressing her willingness to become a producer if she was ever asked to retire, Pickford assumed a tone that Howe compared to an "ultimatum hurled with the force and the curtness of a Mussolini from under a flowery girlish hat." Further, while praising her talent as a strong-willed business leader, Howe labeled her "Premier Pickford" and insisted on the comparison with the Italian politician despite obvious physical differences: "She hasn't as big a jaw as Benito, but it's just as firm and determined."65

Howe viewed a comparison between a Hollywood star and an iconic authoritarian figure as perfectly legitimate because of his competence "as a critic of screen personalities." ${ }^{\prime 6}$ Unsurprisingly, he used this very self-description to justify his prediction about the front-runner of the 1924 U.S. presidential elections. He may have been facetious and self-deprecating when he observed, "As a critic of high integrity, who heralded the discovery of Valentino[, ... ] I realize what I say is 
going to carry considerable weight at the presidential election." But his ironic judgment calls about the effectiveness of media and political communication relied on readers' immediate understanding of their equivalence. "As everyone knows," he remarked, "the chief duty of our executive today is to film and radio well. Mr. Coolidge does not." ${ }^{67}$ A successful model instead was the Duce, whose role as himself in the newly released Hollywood production The Eternal City (1924) provided an enviable alternative.

This month I give three vivas for George Fitzmaurice, who made "The Eternal City" with Barbara La Marr and Benito Mussolini. With Babbie and Benito in the cast the picture certainly should not be lacking in action. ${ }^{68}$

When in 1923 Howe moved on to work as publicity agent for Ramon Novarro, his name remained associated with those of Valentino and Mussolini, both through reports commenting on his activities and through his own writing. Fan magazines knew quite well of Howe's "masquerading" as Valentino. Reporting on Howe's presence as Novarro's lover and publicity agent on the Tunisian set of Rex Ingram's The Arabian, Photoplay sarcastically hinted at the extent to which the writer-promoter had been involved in manufacturing Valentino's public image. An imaginary cable inquiry from the "Lost and Found Department" had located "Mr. Howe in Tunis operating under the name of Rudolph Valentino. He had opened a correspondence school of sheiking and was coining money." 69 Howe never denied his demiurgic contribution. Instead he took pride in his prescience as a talent scout and agent. In early 1925, in one of his regular Photoplay columns, he sought to single out those stars who had shown the "sterner" requirements of stardom over the years..$^{70}$ Howe recognized that the early craze about Valentino, in particular, had to abate eventually, but because of his talent and ambition, he would reemerge a better star. After fighting a "Napoleonic battle" against the studios, he was destined to find a "more stable popularity [. . . ] as a creator of pictures, thus evading the fate that lurked like a serpent amid the roses on the path of sex attraction." ${ }^{11}$ It was the same combination of personal charisma and show business acumen that had made Howe a vocal admirer of Mussolini. His appreciation only increased after an alleged personal meeting with the Duce in Rome, where Howe had gone to visit Novarro on the set of Ben Hur. Following the meeting, Howe described Mussolini as his "favorite star in the current world movie," governing over "the most courteous, ingratiating and genuinely democratic of peoples." ${ }^{2}$

In mid-1925 Howe continued identifying himself with both Valentino and Mussolini. In a tongue-in-cheek article that he prefaced and possibly also wrote about the lives of Photoplay's staff writers, including James R. Quirk, Adela Rogers St. Johns, and himself, he claimed that his real name was "Romeo Galahad Mussolini Leadpipe Howe, Duc de Jambon et des Oeufs" and "in private life" he was "Natacha Rambova's husband." ${ }^{3}$ As these facetious sketches reveal, Howe was identifying himself with the publicity strategies that had enabled Valentino and 


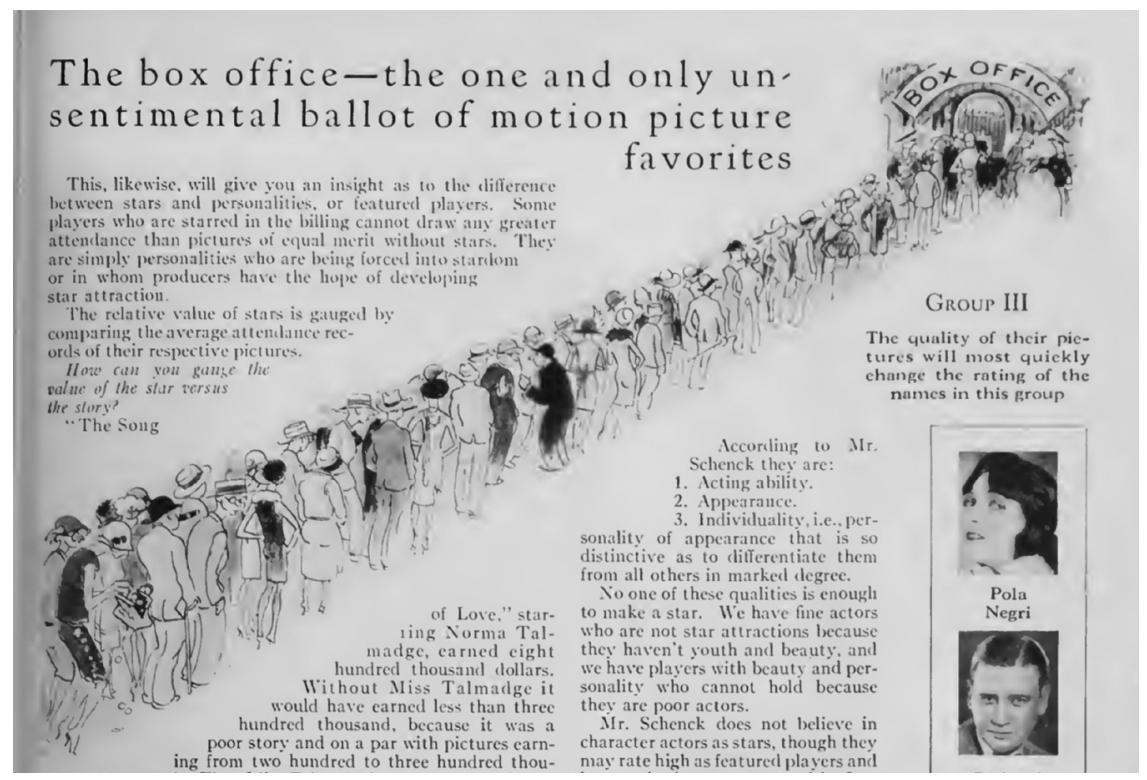

FIGURE 19. Box office as ballot box. Herbert Howe, "Here Are the Real Box Office Stars," Photoplay, June 1926, 29.

Mussolini to become extraordinary stars. In the case of Valentino, Howe's identification was confessional and self-congratulatory. In the case of the Duce, it was a form of distant admiration for the efficiency of the Fascist public relations machine. Howe's decision to place a politician and a film star side by side attests to his understanding of moviegoing as a form of democratic voting, and thus of star appeal (or film fandom, as we might say today) as a form of plebiscitary consensus (figure 19). ${ }^{74}$

When the close relationship between Howe and Valentino came to an end, other figures came to legitimate Valentino's public rapport with the press-and ultimately with the studios. In the 1922-1924 period, two figures in particular had an impact on his career: writer and publicity expert Elinor Glyn, very publicly albeit quite briefly, and Natacha Rambova, Valentino's second wife. In both cases, Valentino's image on and off screen underwent changes that were not, commercially speaking, fruitful. The ensuing crisis, however, sheds light on the resilience of popular appreciation, and over time even nostalgia, for the daring, unapologetic sheik as attempts to tame that original publicity imprint ran into problems.

\section{THE TAMING OF THE SHEIK}

The Four Horsemen and The Sheik represented twin peaks in Valentino's popularity because of the films' narratives, which informed the actor's characterizations and 
their postrelease publicity. The two productions showcased the same dramaturgic trajectory: Julio and Ahmed initially exhibit a raw, primitive, and even dangerous erotic passion before metamorphosing into heroically caring lovers. At the conclusion of the two films, Valentino's characters are either dead or physically wounded, but their personal destinies signal the triumph of romance. Yet, the Divo's press promotion (and self-promotion) mainly insisted on his forceful erotic prowess. Rather than touching equally on the two poles of erotic charge and tenderness, and specifically as a fictional conversion from one to the other, the initial publicity insisted on the dominance of the first, aggressive trait, which imprinted his key mainstream appeal. Still some corrections were needed.

Many in the industry, in fact, felt that the promotion of Valentino's decadent and unremorseful erotic desire had to be balanced by traits and habits that American male spectators could recognize as familiar: professional ambition and physical fitness. That women adored him was as obvious as the fact that men had suspicions about his exotic and threatening foreignness. Men could be brought on board if only they could recognize something conventional in him. That's why Valentino himself, through ghostwritten interviews and direct appeals, took part in a novel publicity discourse that stressed both his suitability for romantic involvement and a distinct, but relatable masculinity. At the same time, the more balanced combination of European and American personal traits had to emerge as a direct, unmediated expression and not as the result of calculated publicity pitches and adjustments. The risk was that his sheik characterizations could appear passé, performative, and inauthentic, and, as such, subject to sarcastic critique and lampooning.

Enter fifty-year-old Elinor Glyn, a consummate expert in selling the glamour and sexual daring of Continental artistry. Her appeal, as her employer Jesse Lasky admitted, derived from her keen understanding of publicity. ${ }^{75}$ Glyn already had used editorials, lectures, advice manuals, and even novels to position herself as a champion of female sensual appeal and a shrewd promoter of exotic encounters, primitive desires, and personal fulfillment. Lasky's decision to invite Glyn to Hollywood to script the next Valentino vehicle, Beyond the Rocks (May 1922), from her own 1906 novel speaks to his desire to exploit the Orientalist glamour that had in both Glyn and the Italian actor two widely recognized testimonials. Beyond the eccentric taste that led her to redecorate her hotel room like a "Persian tent,"76 Glyn had creative and efficient ideas about how to promote herself, her films, and cosmopolitan romance in general.

Today Glyn is mostly linked to a famous publicity stunt, the identification of the erotically charged "It" girl that informed the 1927 film of that title starring Clara Bow. Before that episode, however, Glyn had articulated her own "philosophy of love" centered on women's physical and emotional satisfaction. "Glyn's touch" was virtually antithetical to the ways the It phenomenon linked economic and sexual freedom with consumer culture. Fond of sensationalism more than cultural 
daring, Glyn endorsed women's physical and imaginary gratification through "role plays of dominance and submission" and not through "the cheapening of sexual relations under commodity capitalism." "77 She claimed that American men "could simply not make love" since they treated their leading ladies like "aunts or sisters." 78 Generally advocating "eugenic progress through racial hybridity," Glyn was known for her statements that Latin men's glamorous and Continental model respected, nurtured, and sparked women's different desires more effectively than their Anglo-Saxon rivals did. At the same time, this apparent openness to racial diversity was always conjugated with social elitism and persistent promotion of herself as a master of posh erotic ceremonies. Ultimately, Glyn's infatuation with men of exotic and aristocratic extraction well suited Valentino's public image, including his consistent distance from fellow Italian Americans.

On the surface, Lasky's casting of Valentino in Glyn's Beyond the Rocks appeared most promising. And so did the actor's pairing with Gloria Swanson, who had become a star in her own right as a pioneer of new forms of relationships in the so-called marriage and divorce pictures directed by Cecil B. DeMille between 1919 and 1921. Her lavish personal life and erotically alluring roles could appear cosmopolitan rather than damningly decadent and sinful. Together, Valentino and Swanson could normalize new gender and sexual norms through a strategy of consumer capitalism centered on glamour that made them international fashion trendsetters. As Hilary Hallett rightly points out, "As promise of fulfillment, glamour naturalized, for certain subjects, their sensuality not as a perversion, but a natural, and positive, expression."79 In theory, Valentino and Swanson's transnational glitz added a cosmopolitan cachet to their stardom that deprovincialized both American film culture and its aura in international film markets.

The promotional work showcases the collaboration between Glyn and Valentino as media synergy - from page to screen and back to page. In 1922, Glyn's novel Beyond the Rocks: A Love Story appeared "with illustrations from the Paramount photo-play." One of its pages featured a photograph of Glyn and Valentino, presumably taken on the film's set (figure 20). Two months prior to the film's release, Glyn allegedly ghostwrote Valentino's first extensive contribution to Photoplay. Published in March 1922, it squarely addressed the issue of male leadership in romantic affairs. Entitled "Woman and Love," the article was meant to draw attention to Valentino's style of romance and show that it was fully compatible with that of Swanson ahead of the release of their (and Glyn's) film..$^{80}$ It was not a reprise of the swaggering leadership that Howe had written into Valentino's pronouncements. It was much closer to the narrative trajectory of his earlier successful films, which had portrayed him as an earnest romantic lover, but that contrasted with those films' publicity, which instead had celebrated him as a daring, primitive seducer. In the article, Valentino spoke about passionate romance and openly abhorred the use of sheer physical force. In place of what he termed "the caveman method," he endorsed the more effective "mental caveman" strategy, which would 


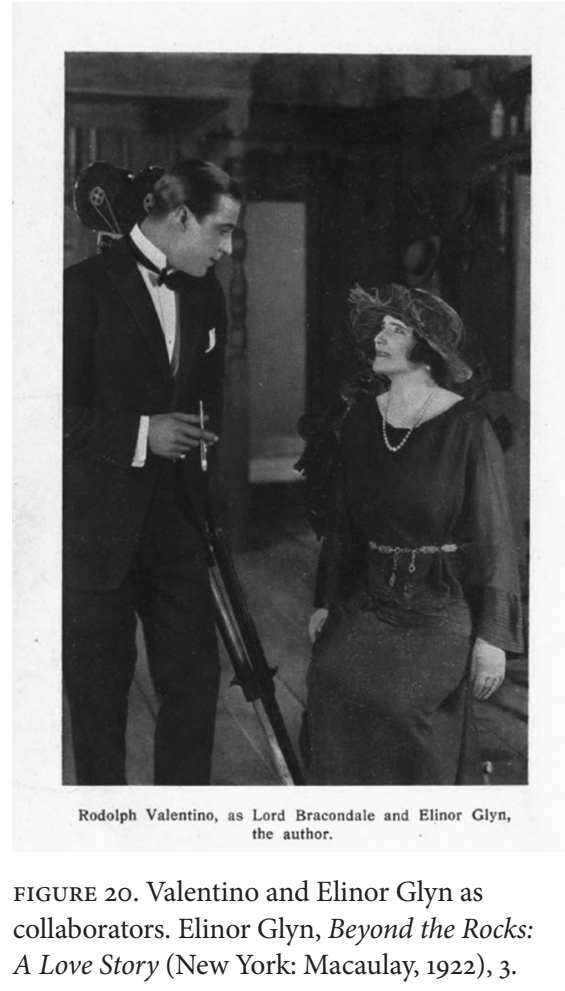

still produce the kind of highly physical romance that he described as "caveman love." "By cleverness, by diplomacy, by superior mental force, by skill," he contended, "that is the way to win a woman." ${ }^{\text {" }}$ For the Valentino that Glyn scripted, effective romantic leadership had to be combined with "tenderness," which the actor described as "absolutely the strongest, most lasting, most trustworthy emotion that a woman can arouse in a man." ${ }^{82}$ The two heart-shaped images-one from The Sheik (1921), the other from Beyond the Rocks (May 1922)_introducing "Woman and Love" exemplify this double strategy, which is summarized in their caption (figure 21). This approach advocated none of the indomitable erotic governance that Howe had woven into Valentino's earlier statements. Unsurprisingly, the public response to the film did not meet expectations.

The move away from Howe's autocratic characterization of Valentino to Glyn's softer version continued in Blood and Sand, which brought the Divo and June Mathis together again. Released in September 1922, the film was based on Ibáñez's best-selling novel and featured Valentino's old daring and primitive characterization for only a few scenes. In its place was a different character, one who is utterly at the mercy of a Spanish vamp, played by Nita Naldi, even though the promotional illustrations stressed the Divo's power of romantic subjugation. ${ }^{{ }^{3}}$ Paramount 


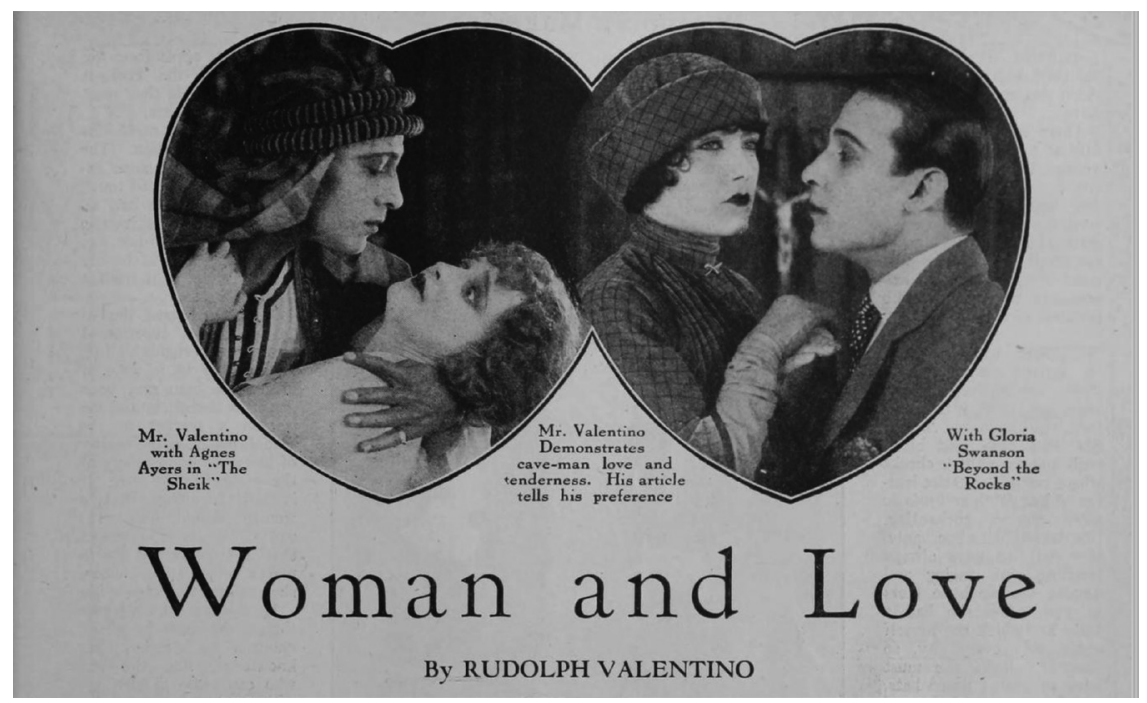

FIGURE 21. Valentino as "caveman" and as tender lover. "Woman and Love," Photoplay, March $1922,41$.

believed that the film was "destined to eclipse the sensational success" of The Sheik because of the volume of its prerelease engagements in New York, Los Angeles, and Chicago. ${ }^{84}$ Directed by the Lasky-appointed Fred Niblo, Blood and Sand initially broke "all records for attendance and receipts at the New York Rivoli during the first week of its runs in the metropolis." ${ }^{35}$ Some reviewers, aware of Mathis's role in once again adapting an Ibáñez work, saw admirable continuity in Valentino's acting as well. They claimed he had "never shown such facility and variety of expression since his work in 'The Four Horsemen.'” Still, they found uniquely praiseworthy "the delightful episodes of romance and the fiery scenes of passion, smouldering and flaming." ${ }^{86}$ Other critics however, found a fatal flaw in Blood and Sand, as they had in Beyond the Rocks. These productions continued the restrained characterization of much of Four Horsemen but disrupted the continuity with the more original and daring sheik character. Commenting on spectators' reactions to Blood of Sand, Variety noted: "It was the struggles of the hero to resist the temptation of the siren widow that made them chuckle. The spectacle of the erstwhile sheik holding a beautiful woman at arm's length was too much." While getting Hull's name wrong, the review had it right when it explained audiences' disappointment:

Valentino's performance of Mrs. Hutchinson's [sic] "Sheik" fixed his status among the fans as a super-heated love maker and the sudden switch to a St. Anthony type comes as a shock. ${ }^{87}$

Mathis and Glyn were not the only enablers who sought to distance Valentino from earlier publicity strategies. An even more daring taming of the Sheik came from his 
wife, the ambitious Natacha Rambova. As Glyn had done, she too sought to advise Valentino on his artistic and professional decisions. Over the years Rambova had grown discontented with Valentino's popular role as the sensual Oriental despot. She deemed it a form of surrender to commercial exploitation and contrary to the artistic ambitions she projected onto his star persona. She wanted him to be her "ultimate work of art"; thinking of herself as the new Sergei Diaghilev, she hoped Rudy "would be her Nijinsky." 88 When she became costume designer for the mystical drama The Young Rajah (November 1922), which Mathis had written for Valentino, Rambova drew on Nijinsky's choreography for Debussy's L'Après-midi d'une faune. Wearing the costume his wife had designed and posing as a languid Hindu prince dressed as a fawn, Valentino was unrecognizable to many. The film's story, together with his costumes and poses, contributed to its abysmal commercial failure. They conveyed a disturbing version of masculinity, ambivalent and heterodependent (even on Rambova's elitist artistic ambitions), that proved too much a departure from his daring Sheik heroings. ${ }^{89}$

The last film Valentino made before the breakup with Famous Players and his self-inflicted hiatus presents a narrative trajectory diametrically opposed to that of The Sheik. Released as Moran of the Lady Letty (December 1922), the film was adapted for the screen by Mathis from Frank Norris's eponymous novel. The story's starting point is comparable to that of The Sheik: Moran, the tomboy female protagonist, is a superb sailor who "has never been in love" and who despises men's penchant to command..$^{90}$ Her coprotagonist, played by Valentino, is the San Francisco socialite Ramon Laredo, who is bored with his life until he gets shanghaied onto a pirate ship and finally experiences "reality, savage reality." ${ }^{91}$ Derided and forced to work, he reveals an unexpected strength and dexterity, which gains him respect and a leading role on the ship. ${ }^{92}$ When the crew captures another ship, Laredo rescues the only surviving sailor, Moran. Upon learning Moran is a woman, the captain wants her for himself. Defending her means that Laredo has to kill, but nothing deters him from doing just that because "the blood of the primeval tiger man leaped through him." ${ }^{3}$ Laredo's heroism saves Moran and transforms both. Before his newfound combination of physical violence and tenderness, an awakening Moran acquiesces to love: "You win, mate," Moran said, "And I love you for it."

Unsurprisingly, critics very much appreciated this combination of eroticism and sheer violence. "The handsome Rodolph Valentino showed he could wield a wicked fist with as much art as he can make love," wrote Maude Cheatham of Motion Picture Classic. ${ }^{94}$ But the trajectory of his character was more a conciliation of "caveman love and tenderness" (actually, tenderness and caveman love) than a daring display of Sheik-like desire. It once again confirmed the importance of the Sheik's first imprint which, like a picture in everybody's head, could even lend itself to lampooning. For instance, a month after the "Woman and Love" article, in an April 1922 contribution to Photoplay, writer-cartoonist Richard W. "Dick" 
Dorgan satirized the Italian actor's most famous film role. Dorgan described Valentino's gazing at Diana as the "'I gotcha look' à la Ben Turpin” (anticipating by a year Turpin's own lampooning of the actor's role in the short The Shriek of Araby). ${ }^{95}$ In what Emily Leider described as Dorgan's "slang review" of The Sheik, in which he never mentions Valentino by name, Dorgan questions the actor's contribution to the construction of his own character. He even "outs" Valentino's close publicity collaboration with Glyn, although Glyn had not exactly endorsed the Sheik performative style. ${ }^{96}$ "He must have been reading Elinor Glyn closely or else be stealing Theda Bara's stuff," Dorgan wrote before ironically alluding to the rigid prescriptions that Wilson had prepared for the Versailles Peace Conference, "'cause he had all the fourteen points down great, with a couple of the amendments tacked on." ${ }^{97}$ Similarly, in 1923 and 1924, populist and politically vocal vaudeville star Will Rogers caricatured several stars, including Valentino's stylized and histrionic acting style, first in the two-reel Uncensored Movies and later in Big Moments from Little Pictures, both produced by Hal Roach. ${ }^{8}$

Others took the primary scene of the Sheik-like unrepentant lover seriously, often by insisting on a theme that the industry held as essential: a star's personal, direct, and extraordinary appeal to American audiences. A most indicative example of these contributions appeared with the title "The Vogue of Valentino" in Motion Picture Magazine in February 1923. Months into Valentino's self-induced exile from the screen due to his refusal to abide by Famous Players' contract, "one of American's most eminent psychologists" sought to explain "the sex psychology underlying the tremendous popularity of Rodolph Valentino."99 The actor successfully inflamed "the feminine imagination of an entire country", the anonymous psychologist claimed, because he "epitomizes the lure of romantic passion [, . . . ] the brigand of love." ${ }^{100}$ To make sense of his popularity, this expert argued that Valentino was "at once graceful and aggressively masculine" and that his expression suggested "a suspicion of cruelty" even though "he appears capable of salving whatever cardiac wounds he might inflict." ${ }^{101}$ The psychologist described the actor's exotic charm as more Latin than Italian, saying he was accustomed to clothing himself "with spectacular elegance," which did not threaten his masculinity, "for the modern feminine sense of beauty contains that heritage from ancient times which delighted in the gorgeousness of male attire." Finally, the unnamed psychologist asked the critical question: "What condition of affairs in America has brought about Valentino's present status?" He answered with an indictment echoing Valentino's 1921 self-promotion and Glyn's ghostwritten contribution. According to the expert, the Divo's success revealed that "American men are not lovers! [. . .] The American business man has little or no imagination for aesthetic activities and sentimental pastimes. All his imagination has been focused and expended on commercial enterprise. [...] The result is, the American woman is starving for romantic love."102

A year later, Adela Rogers St. Johns adopted the same perspective of a direct relationship between star and film audiences by seeking to explain both what had made 
Valentino so attractive and why men despised him. She deemed it "manifestly silly" that most women "will deny flatly that they are ever attracted by anything in men but grand and noble character." In reality, she argued, "the first essential element of love being flattery, a woman's vanity is most vitally touched by a man's desire for her." Valentino is women's idol, she wrote, because his lure "is wholly, entirely, obviously the lure of the flesh." ${ }^{103}$ Along with women's favorable reactions, St. Johns also explained that men "resented Rudolph's popularity [. . .] because they believe he appeals to the worst side of women."104 What St. Johns clearly had in mind was Dorgan's notorious 1922 "A Song of Hate," in which the famous writer-illustrator expressed his distaste for Valentino's physical appearance, acting style, and success and presumed he was speaking on behalf of all American men. Dorgan used such explicitly racist tones that one might even assume an ironic hyperbole:

I hate Valentino! All men hate Valentino. I hate his oriental optics; I hate his classic nose; I hate his Roman face [. . .] . I hate him because he dances too well; I hate him because he's a slicker; I hate him because he's the great lover of the screen; I hate him because he's an embezzler of hearts [...] . What! Me jealous?-Oh, no-I just Hate Him. ${ }^{105}$

What Dorgan's piece, St. Johns's comments, and the anonymous psychologist's praises all point to is the novelty of Valentino's dominating style of governance of romance that had inaugurated his popularity in late 1921 and had framed women's expectations and men's frustrations ever since. Yet, given the dominance of female spectators among American film audiences, what tamed the Sheik was not the displeasure he provoked in male moviegoers, but the abandonment of roles and publicity coverage that rested on such "celluloid naughtiness." ${ }^{106}$ During the next four years, he either chose roles that, like the pre-Sheik Camille, presented him more as a romantic follower or victim of a woman's love, or he just disappeared from the screen, as he did throughout 1923 until early 1924 due to his rift with Famous Players. During this hiatus, Photoplay even wondered "whether or not Rudolph Valentino's long absence from the screen would affect his drawing power on his return." The answer was often in the negative. ${ }^{107}$ If coverage of his divorce from Famous Players-Lasky did not abate, neither did his screen presence diminish. But it was now a nostalgic visibility. Film distributors started rereleasing and retitling his older films, including The Married Virgin (1918) as Frivolous Wives, and gave him new prominence in the credits.

Meanwhile, Valentino and a coterie of promoters launched a series of publicity initiatives that were meant to keep his name in the press during his diminished screen visibility. The unintended consequence, however, was that they muted the excitement of his most daring characterizations. For instance, Valentino contributed to his own publicity by collaborating with the publisher Bernarr Macfadden on several projects aimed at smoothing his rougher edges and Americanizing his masculinity. ${ }^{108}$ In 1922, Macfadden published a two-part autobiography of the actor, entitled "The Romance of Rudolf Valentino's Adventurous Life (By Himself)," 
and in 1923 he increased the Italian actor's print exposure. ${ }^{109}$ First came a book of poetry, entitled Day Dreams. Next was a series of articles on Valentino's bodybuilding habits that appeared in Physical Culture and Movie Weekly and were aimed at showcasing how fully attuned the actor was to the American male values of sportsmanship and endurance. These were followed by a manual of physical culture, How You Can Keep Fit, allegedly authored by Valentino himself. This eightypage volume featured dozens of photographs of the bare-chested Hollywood star engaged in physical exercises (figure 22). ${ }^{110}$ In 1925, after he had resumed his acting career, Valentino also multiplied his written contributions to Photoplay.

Perhaps the most peculiar initiative was the lucrative, but also unflattering, decision to accept the business proposal of an unknown lawyer, George Ullman, when Valentino was not receiving a salary from Hollywood and needed money to support his lavish lifestyle. Ullman, who would play a key role in the last years of Valentino's life and beyond, devised this publicity stunt for his employer, the beauty firm Mineralava. ${ }^{111}$ The idea was a well-promoted national tour in which Valentino and his wife, clad in Argentinian costumes, would repeat the tango routines of the Four Horsemen, praise Mineralava beauty products, and judge dancing and beauty contests (figure 23). While a Famous Players' injunction prevented him from appearing on a legitimate stage as an actor, nothing prevented him from dancing with his wife in public in other locations. The three-month tour, from mid-March to mid-June 1923, touched eighty-eight cities in the United States and Canada. Valentino and his wife earned \$7,00o a week. The winners of the local beauty contests participated in a highly publicized event in New York City, where Valentino was crowned the winner of the national competition. ${ }^{112}$ The final Mineralava performances took place just as bookstores began selling Valentino's volume of poetry.

The tableau of the Divo and his wife inspired affectionate mockery, but it was also the subject of serious discussion about the commercial appeal of an actor who had followed his wife's career advice to his ruin. ${ }^{113}$ When Valentino reappeared on screen in Monsieur Beaucaire (August 1924) and then in A Sainted Devil (November 1924), the reviews anticipated a familiar argument. Monsieur Beaucaire exhibited a lavish and artistic quality, but "something has happened to the Valentino of "The Sheik,'” wrote Photoplay editor James R. Quirk. "Rudy," he explained, “is trying to be an actor at the expense of the personality that made him a sensation." Even though he played the part of a French prince, "he doesn't look a bit dangerous to women." Quirk opined. "The fact of the matter is that they like their Rudy a little wicked. He had what is known in pictures as 'menace' to a higher degree than any actor on the screen." ${ }^{114} \mathrm{~A}$ few pages earlier, the editors made the same point with regard to A Sainted Devil. A caption for one of the photographs depicting an all-too-romantic love scene referred to the film as "The Taming of the Sheik." 115

Quirk explicitly linked the flops of Valentino's films to his wife. He blamed her for the professional breakup between Valentino and J. D. Williams of Ritz-Carlton Pictures apparently over commercial results and future plans. "Mrs. Valentino's 


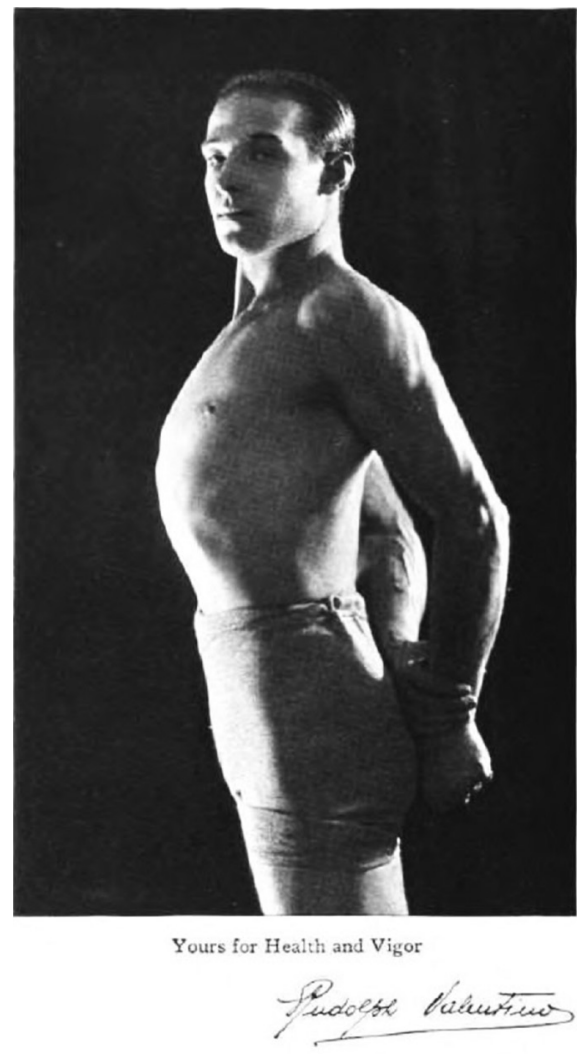

FIGURE 22. Frontispiece in Valentino's How You Can Keep Fit (New York: Macfadden, 1923).

strict management of her husband is not consistent with the career of a screen sheik," Quirk noted, and "the picture of a devil-may-care Latin lover with a wife-manager is rather inconsistent." Referring to whether Valentino had control over his career, he concluded: "The illusion must be maintained""16 The cartoon accompanying his article made the same point about Valentino's ill-advised commercial path. The syndicated artist-humorist and cartoonist Reuben Lucius Goldberg, widely known as the inventor Rube Goldberg, created the two-page cartoon (figure 24). On the left, it features a crowd of thousands of spectators in line to enter a movie theater to watch films starring Ramon Novarro and Antonio Moreno, as the two posters indicate. On the right, it features Valentino and Rambova on a pedestal inscribed with "The Valentinos." While uttering slogans associated with their anti-studio stance, they find themselves without an audience, except for a single disheveled spectator, whose cry "Atta boy, Rudy!" captures ironically the actor's disastrous dependency on his wife's beliefs. 


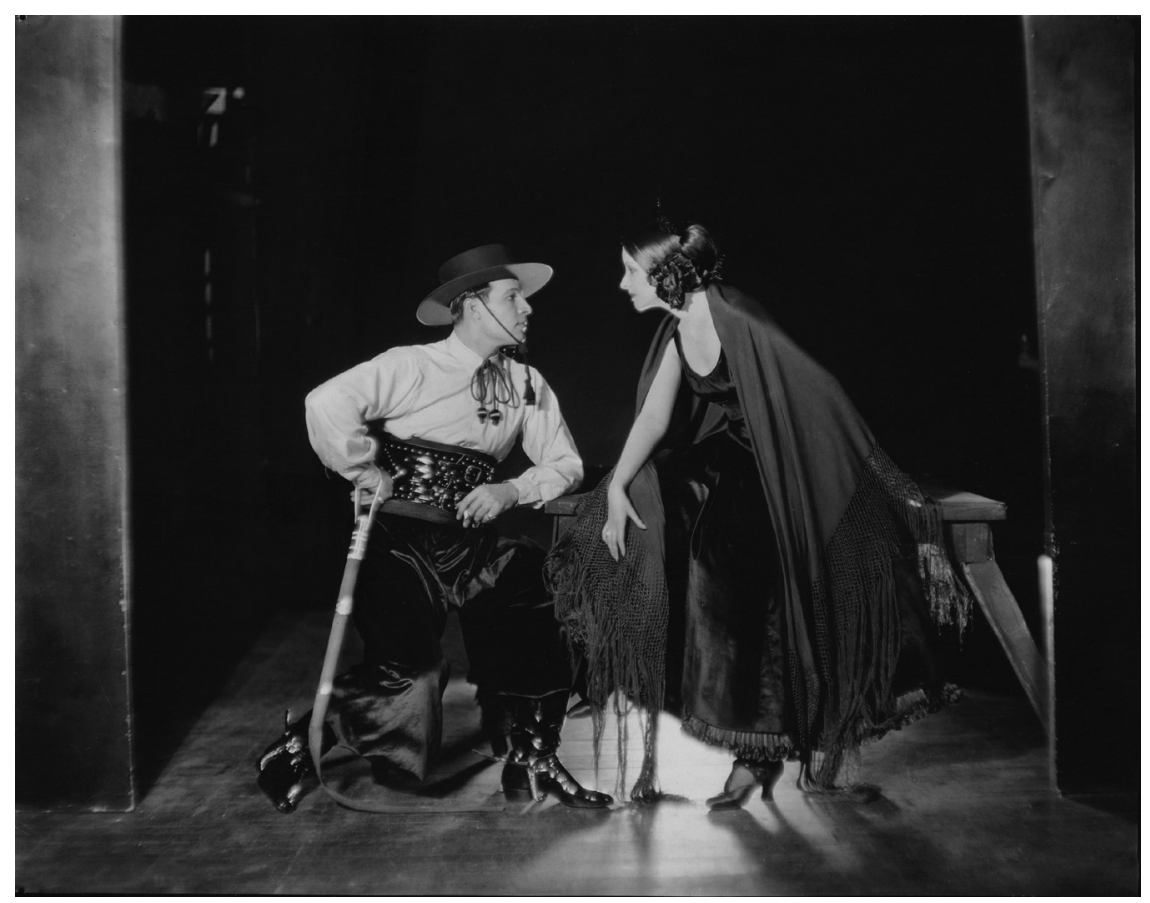

FIGURE 23. Valentino and Rambova as tango dancers on the Mineralava tour. Rudolph Valentino, no. 49, Core Collection Biography Photos, Academy of Motion Pictures Arts and Sciences. By permission of AMPAS.

While Rambova was advising Valentino on his professional choices and intervening directly on scripts and art direction, the newly hired George Ullman was taking care of the actor's finances, contractual obligations, and publicity. Ultimately Rambova and Ullman came to have very different views about Valentino's post-Mineralava-tour film career. Initially, as Evelyn Zumaya has argued, Ullman "crafted his press releases with the intention of transforming the public's perception of Rudy from that of marauding, sex-obsessed Sheik to the courtly Monsieur Beaucaire." ${ }^{117}$ He successfully negotiated Valentino's contractual closure with Famous Players-Lasky, resulting in Monsieur Beaucaire and A Sainted Devil, and began shepherding a collaboration with J. D. Williams. Rambova meanwhile began working on the screenplay for a film entitled The Hooded Falcon, adapting it from the story of El Cid, but her dismissal of June Mathis, initially co-opted for the script, confirmed Hollywood's perception of her disastrous understanding of the film business. When Williams realized that the Valentinos had no sense of budgetary limits, he walked back from promises and agreements and made Ullman inform them that the project was shelved. Eventually, unbeknownst to the Valentinos (but not to Ullman), Williams sold the distribution rights of The 

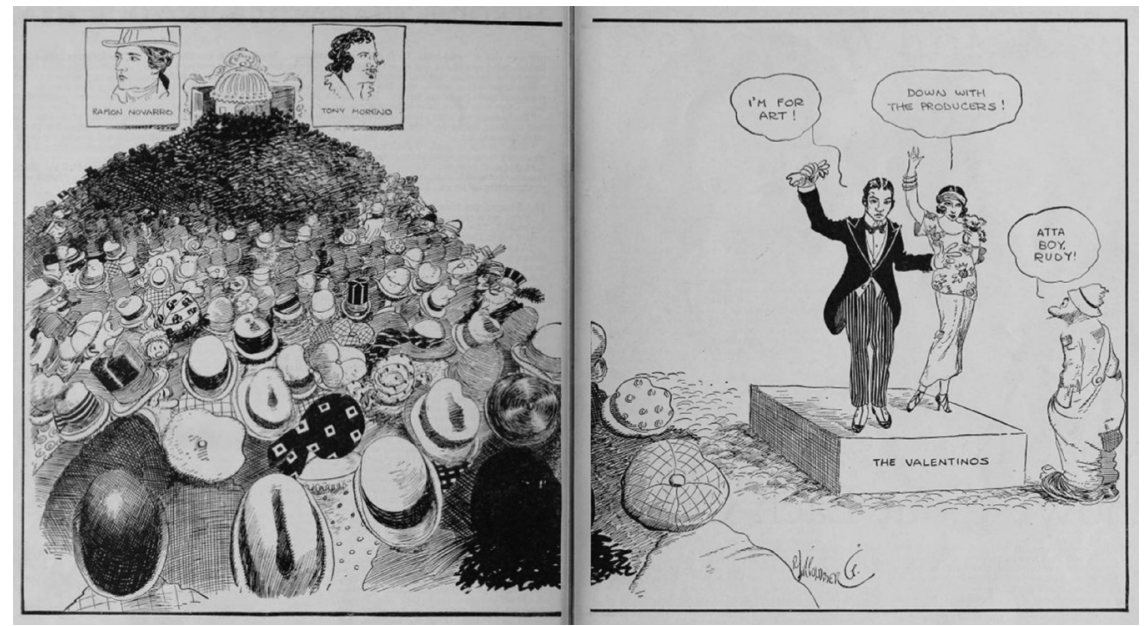

FIGURE 24. Rube Goldberg's cartoons about Valentino. James R. Quirk, "Presto Chango Valentino!" Photoplay, May 1925, 36-37.

Hooded Falcon to Paramount, which later also distributed Cobra (Ritz-Carlton; November 30, 1925) - a contemporary drama featuring Valentino in the role of a rather un-Sheik-like Italian count. When Ullman informed the Valentinos that he had started negotiations with United Artists on possible future productions, Rambova was quite happy about the prospect until she read the contract. There was no executive or creative role for her. The Italian actor signed it anyway on March 30, $1925 . .^{118}$

Valentino's signature on the contract led to an insurmountable rift between the pair and eventually led to the end of their relationship. They were divorced by mid-January 1926, although news of the split did not leak until much later. ${ }^{119}$ United Artists had clear ideas about what to do with Valentino. It was sufficient to pay attention to how editorials and letters to the editors, public commentators, and private individuals alike had long argued that Valentino's popularity waned the moment he stopped being a ruthless and fascinating leader in love affairs. A letter published in Photoplay in June 1926 and written by a lady fan in California made the best case. In The Four Horsemen and The Sheik, she wrote, "Rudolph showed us the gay, passionate Latin lover-a juggler of women's hearts. A bit ruthless, perhaps, but oh, how fascinating!" Since then, she claimed, nothing had ever been the same:

Now, only Rudolph's perfect manners save him from being completely Americanized. [...] We do not want to see Rudolph enslaved by Dagmar Gogowsky or even Nita Naldi [both had played opposite Valentino in The Sainted Devil]: we want to see Nita and Dagmar enslaved by Rudolph. ${ }^{120}$ 
By early 1926, fan magazines were covering his "marriage suspension" from Rambova, his affairs with Pola Negri and Vilma Banky, and the shooting of The Son of the Sheik with Agnes Ayres and Banky. The industry had been welcoming Valentino's return to the fold of expert playmakers with open arms. ${ }^{121}$ Already in late 1925, the New York World had anticipated the shift in an article eloquently subtitled "Advisers of the Film Star Would Make Him a Real He-Man," which insisted that "the pastels will go [and] virile oil paintings [would] take their place." ${ }^{122}$ The exploitation agents knew how to shape his image back to an exciting one, on and off screen, and even took advantage of his unexpected hospitalization and surprising death occurring just a few months later. 